DOI: $10.19195 / 2300-7729.36 .18$

\author{
JAKUB MACIEJ ŁUBOCKI \\ Uniwersytet Wrocławski
}

\title{
Sprawozdanie z wernisażu podsumowującego projekt digitalizacji kroju pisma Bona
}

25 listopada 2017 roku w Warszawie miało miejsce niecodzienne wydarzenie ze świata typografii. Tego dnia w niebanalnych wnętrzach Reduty Banku Polskiego ${ }^{1}$ (przy ulicy Bielańskiej 10) rozpoczął się wernisaż podsumowujący projekt digitalizacji kroju pisma Bona. Kiedy myślimy o wernisażu i digitalizacji, przychodzą nam do głowy raczej inne skojarzenia niż kształt litery — wernisaż to najczęściej święto obrazów czy rzeźb, digitalizacja to z kolei skanowanie cennych dokumentów. Tymczasem, dzięki przedsięwzięciu - które już jest określane jako „najbardziej spektakularny projekt w historii polskiej typografii” — zespołu Mateusza Machalskiego, myślę, że powinniśmy na trwałe włączyć do znaczenia słowa ,wernisaż” wydarzenie promujące nowy krój pisma, a przez digitalizację rozumieć także ucyfrowienie kroju dawnego. Jak do tego doszło?

$$
* * *
$$

Krój Bona został zaprojektowany w 1971 roku przez Andrzeja Heidricha ${ }^{2}$. Mógł mieć zastosowanie głównie akcydensowe, ponieważ istniał jedynie w od-

${ }^{1}$ Właściwie: budynek Banku Polskiego. Zaprojektowany w stylu neorenesansowym z wpływami modernistycznymi i zbudowany w latach 1907-1911 od początku na potrzeby bankowości (najpierw mieścił się tu bank rosyjski, a następnie polski). W 1944 roku, w trakcie powstania warszawskiego, został zamieniony na redutę powstańczą (stąd obecna nazwa, ułatwiająca odróżnienie od gmachu Banku Polskiego przy placu Bankowym) i z tego powodu stał się punktem ciężkich walk. Znacznie uszkodzony w ich trakcie został częściowo wyburzony w latach sześćdziesiątych XX wieku (pozostawiono jedynie zachodnie skrzydło, natomiast w miejscu pozostałych części wzniesiono w 2012 roku, z zachowaniem ocalałych zabytkowych elementów ścian i fundamentów, biurowiec Senator, bardzo swobodnie nawiązujący bryłą i podziałami fasady do pierwotnej architektury budynku). Wernisaż miał miejsce w sali stworzonej w historycznej części budynku.

${ }^{2}$ Urodzony w 1928 roku, w 1954 roku ukończył studia na Wydziale Grafiki Akademii Sztuk Pięknych w Warszawie. Autor licznych prac graficznych do książek (ilustracje i okładki), ale znany przede wszystkim z prac użytkowych: projektów znaczków pocztowych, ekslibrisów, doku- 
mianie kursywnej i posiadał ograniczony zestaw znaków, który umożliwiał wprawdzie skład prostego tekstu w języku polskim, jednak nie pozwalał na swobodny skład dziełowy dłuższej wypowiedzi o standardowym choćby stopniu skomplikowania (z powodu między innymi braku odmiany prostej i pogrubionej, braku znaków diakrytycznych dla innych języków, braku możliwości składu formuł matematycznych i innych pozajęzykowych treści). Niezależnie od możliwości, jakie oferowała Bona, a przede wszystkim mimo jej niewątpliwego piękna (opisywanego tymi słowy przez Machalskiego: „krój jest antykwą z delikatnym kontrastem oraz włoską proweniencją. Klasyczne i z wyczuciem skonstruowane proporcje znaków przełamane są $\mathrm{w}$ wielu momentach odważnymi rozwiązaniami”3, wraz z nadejściem ery komputerowego składu, dopóki istniała jedynie w postaci zecerskich czcionek (i to w tylko w kilku rozmiarach), nie miała szansy na dalsze występowanie w przestrzeni: kroje, które nie mają cyfrowej reprezentacji w postaci fontu, umierają.

Szczęśliwie losem Bony zainteresował się Mateusz Machalski ${ }^{4}$, który jest pomysłodawcą całego przedsięwzięcia (nie tylko relacjonowanego tu wernisażu) i głównym koordynatorem projektu. To on w roku 2012, w trakcie swoich studiów, pierwszy raz zetknął się z kasztą Bony w Zecerni Akademii Sztuk Pięknych w Warszawie. Pierwotnie zakładał jedynie proste ucyfrowienie materiału zecerskiego - tylko w takim kształcie i zasobie, w jakim pozostawił go Heidrich. Jednak słabej jakości podstawa, na której się opierał (ksero pełnego zestawu znaków), niedostateczne opanowanie warsztatu literniczego, a przede wszystkim sugestia Mariana Misiaka, aby doprojektować prostą i pogrubioną odmianę kroju, sprawiły, że Machalski projekt zarzucił (powstałą wówczas wersję sam autor określa jako „nieudolną”). Przypadkowe spotkanie Leszka Bielskiego w 2016 roku dało impuls powrotowi do pracy nad digitalizacją Bony. Tym razem podstawą prac nie była kserokopia, lecz najbardziej oryginalne tworzywo, z jakim może mieć do czynienia tylko typograf — prawdziwe kartony Heidricha z wyrysowanymi odręcznie wszystkimi znakami kroju i ich szkicowymi odmia-

mentów (dowody osobiste, paszporty), a przede wszystkim banknotów (od 1974 roku wszystkie polskie banknoty są jego autorstwa), oraz - co mniej kojarzy się z projektowaniem graficznym — różnego rodzaju insygniów: herbów miast i województw, odznaczeń wojskowych, policyjnych i państwowych, pieczęci.

3 Andrzej Heidrich, Mateusz Machalski, Leszek Bielski, Ania Wieluńska, Michał Jarociński, Bona Nova, Warszawa 2017, s. 30.

${ }^{4}$ Urodzony w 1989 roku, w 2014 roku ukończył studia na Wydziale Grafiki Akademii Sztuk Pięknych w Warszawie. Jego twórczość obejmuje szerokie spektrum prac z pogranicza grafiki i typografii. Szczególnie chętnie zajmuje się projektowaniem identyfikacji wizualnych (między innym gali Nagrody Solidarności im. Lecha Wałęsy) oraz krojów pism (między innymi bogaty w odmiany Tupper Serif czy oparty na założeniach typografii wernakularnej Nocturne Serif). Oprócz tych udanych realizacji w swoim dorobku ma inne prace o charakterze użytkowym — plakaty, grafiki, logo (między innymi warszawskich Pawilonów), okładki płyt (zespołów Yorüba czy Ю $\backslash \mathrm{Yu}$ ), a także projekty graficzne książek (Waldemar Frydrych, Major, Warszawa 2013). 
nami. Dotarcie do tych materiałów unaoczniło autorom projektu, że pierwotna koncepcja została w detalach nieco wypaczona przy transponowaniu jej do formy fizycznych czcionek (różnice w grubości liter, detalach, proporcjach szeryfów). Ostatecznie po nieznacznych korektach, wynikających z dostosowania kroju do środowiska cyfrowego, powstała zdigitalizowana wersja pierwotnego materiału. Była to baza do przygotowania odmiany prostej, pogrubionej i kapitalików. Do ich wykonania posłużyła wnikliwa obserwacja innych projektów Heidricha, na podstawie których można było uchwycić unikalny „klimat” swoistych rozwiązań piśmienniczych, jakimi się posługiwał. W ten sposób w pozostałe dwie odmiany można było tchnąć autentycznego ducha autora Bony — tak, jakby sam Heidrich je zaprojektował.

W tym miejscu należy szczególnie mocno podkreślić, że Andrzej Heidrich uczestniczył w pracach całego zespołu (którego członkami byli także Leszek Bielski, Anna Wieluńska i Michał Jarociński ${ }^{5}$ ) i na każdym etapie prac konsultowano z nim wszelkie wątpliwości i przedstawiano różne warianty do akceptacji. Dzięki temu zachowano szacunek dla pierwotnej koncepcji Bony, za którą odpowiadał Heidrich — taką etykę pracy należy wyraźnie pochwalić. Istotne jest również to, że autorzy digitalizacji uznali projekt za „dobro wspólne” i wiele decyzji co do ostatecznego kształtu rozwiązań zastosowanych w kroju poddawano publicznej dyskusji (swoje uwagi zgłaszali tacy tuzowie polskiej typografii, jak Robert Oleś, Andrzej Tomaszewski czy Adam Twardoch, a ostatecznie przed opublikowaniem kroju przetestowało go ponad sto pięćdziesiąt osób w celu wychwycenia wszystkich błędów, jakie mogły się wkraść). Ostatecznie, w stosunku do pierwotnego zestawu znaków, krój Bona Nova został wzbogacony nie tylko o kursywę i pogrubienie, lecz także o cyfry proste (Bona miała jedynie cyfry nautyczne), poszerzono zestaw ligatur (a także opracowano ligatury ozdobne) i liter zamaszystych (eleganckich wariantów z przedłużonymi formami liter), opracowano kapitaliki, ułamki, górną i dolną frakcję, warianty glifów, komplet znaków diakrytycznych, symbole (muzyczne, matematyczne, walutowe i tym podobne), hedery, rączki i innego rodzaju ozdoby drukarskie.

Ostatecznie font Bona Nova składa się z ponad tysiąca dwustu znaków na każdy wariant kroju, dostępny w klasycznej triadzie odmiany podstawowej oraz dwóch odmian ozdobnych: tytułowej (Bona Title) i konturowej (Bona Sforza), umożliwiających wszechstronne wykorzystanie w praktycznie każdej sytuacji publikacyjnej (w wydruku i elektronicznie). Font jest możliwy do pobrania ze strony: https://capitalics.wtf/pl/font/bona-nova — odmiana podstawowa udostępniana jest bezpłatnie na zasadzie otwartej licencji, a odmiany ozdobne można zakupić. Jest to bardzo ciekawy sposób rozpowszechniania fontu i, co należy podkreślić, bardzo słuszny: darmowy dostęp do odmiany podstawowej zapewni jej szybką i szeroką popularność (już mówi się, że będzie to krój „kultowy”) oraz

5 Wszyscy są także absolwentami Wydziału Grafiki ASP w Warszawie. 
nakłoni chętnych do zakupu pozostałych odmian, co z pewnością finansowo wesprze całe przedsięwzięcie. A koniecznie trzeba dodać, że to nie jest jego koniec! W coraz bardziej realistycznych planach twórcy Bony Novej myślą o przygotowaniu znaków cyrylicy i alfabetu wietnamskiego, a także odmiany bezszeryfowej (pod nazwą Sigmund — od imienia męża królowej Bony).

\section{$* * *$}

Zanim przejdę do zasadniczej części sprawozdania, trzeba jeszcze poświęcić kilka słów publikacji towarzyszącej wydarzeniu ${ }^{6}$. Wydana w nakładzie siedmiuset egzemplarzy, 96-stronicowa, bogato ilustrowana, zawiera obszerną rozmowę Leszka Bielskiego i Mateusza Machalskiego z Andrzejem Heidrichem (o jego twórczości, rozwoju zawodowym i szczegółach powstawania samej Bony), drobiazgowo opisany proces digitalizacji kroju (w tym omówienie problemów, na jakie natknęli się autorzy, wariantów ich rozwiązań i uzasadnienia wyboru jednego z nich — to sprawia, że publikacja staje się praktycznym podręcznikiem do digitalizacji krojów, a już na pewno przewodnikiem, jak to zrobić dobrze) oraz specimen całej rodziny. Tym, którzy nie dotarli na wydarzenie, a chcieliby wejść w posiadanie egzemplarza tej cennej pozycji, pozostaje wizyta w galerii „Salon Akademii” na Krakowskim Przedmieściu 5, gdzie jest dostępna, lub pobranie e-booka ze strony projektu: http://bonanova.wtf/.

$$
* * *
$$

Przestrzeń, w której odbywał się wernisaż, była podzielona wielkoformatowymi wydrukami, przedstawiającymi specimeny kroju i przykłady jego zastosowania (mecenasem tych wydruków była Polska Wytwórnia Papierów Wartościowych). Całość - nie tylko specimeny, lecz także minimalistyczne oświetlenie — była utrzymana w kolorach identyfikujących krój: czarnym, czerwonym i białym. Podobnie materiały towarzyszące projektowi (publikacja książkowa, strona internetowa i tym podobne). Można odbierać to w ten sposób, że z jednej strony Bona jest krojem polskim i stąd barwy narodowe, a z drugiej — krojem o uniwersalnym, ponadnarodowym zastosowaniu, tak jak cała „,czarna sztuka”, jaką jest drukarstwo. W tych trzech kolorach przygotowanych zostało również dwadzieścia sześć inicjałów, których wystawa towarzyszyła wydarzeniu. Zaprojektowane przez dwudziestu sześciu grafików i typografów w charakterystycznych dla siebie stylach były różnorodne w formie — od małych miniatur sytuacyjnych po

\footnotetext{
${ }^{6}$ A. Heidrich et al., op. cit., Warszawa 2017.
} 
kompozycje czysto geometryczne - i bardziej przypominały graficzne wariacje na temat niż inicjały gotowe do zastosowania w druku. Co ciekawe, także wielu z gości utożsamiło się z tą identyfikacją kolorystyczną i mieli z sobą czerwono-czarne akcenty lub elementy garderoby.

Wydarzenie rozpoczęło się po godzinie dwudziestej, od udanego występu bardzo młodych utalentowanych braci — Jakuba i Mateusza Izdebskich — którzy zaprezentowali pięć utworów muzyki klasycznej na skrzypce w duecie i solo (zaproponowali publiczności między innymi utwory Jana Sebastiana Bacha). Następnie rozpoczęła się krótka część oficjalna. Dosłownie po kilka zdań, głównie wyrazów radości i podziękowań, wygłosili Mateusz Michalski, Andrzej Heidrich i Katarzyna Lisowska-Byster (przedstawicielka Reduty). Nie powinno to zupełnie dziwić: ten krój pisma mówi sam za siebie i nie wymaga żadnych dopowiedzeń, a to, co warte usłyszenia o okolicznościach całego przedsięwzięcia, można znaleźć w publikacji. W tej części wydarzenia zabrakło jedynie poświęcenia większej uwagi prezentowanym inicjałom — gospodarze tylko zwrócili uwagę, że towarzyszą nam te prace, jednak nie zaplanowali żadnego omówienia czy dyskusji na ich temat. A szkoda, bo w tej sytuacji jedynie można było się domyślać, że literze H towarzyszyła historyjka o żarłocznym wilku, ponieważ jest nakłaniany do spożycia herbaty dla nerwusów, a literze $\mathrm{R}$ - sugestywnie przedstawiona pacyfikacja rebelianta. Inne skojarzenia były jeszcze trudniejsze do zidentyfikowania. Całość wydarzenia dopełniało przygotowane przez organizatorów afterparty.

Wydarzenie miało bardzo wysoką frekwencję: sporych rozmiarów sala Reduty była pełna, co na pewno jest efektem intensywnej promocji w mediach społecznościowych i portalach informacyjnych, a także w radiu (Radio Dla Ciebie) i prasie („Notes na 6 Tygodni”). O chęci wzięcia udziału w wernisażu poprzez wydarzenie na Facebooku poinformowało pięćset dziewięć osób (a dalszych siedemset trzy było nim zainteresowanych) i z dużą dozą prawdopodobieństwa można przyjąć, że większość z nich dotrzymała słowa i pojawiła się tego dnia przy Bielańskiej 10. To, że rozdano wszystkie pięćset egzemplarzy publikacji towarzyszącej wydarzeniu, jakie przygotowali dla gości organizatorzy, tylko potwierdza tę tezę. Sama wystawa w Reducie była dostępna dłużej niż tylko w trakcie wernisażu — do 1 grudnia 2017 roku w godzinach 10.00-17.00.

$$
* * *
$$

Należy mieć nadzieję, że nie jest to ostatni wernisaż kroju pisma w Polsce. Ale żeby tak mogło się stać, muszą pojawić się następcy Machalskiego, gotowi zmierzyć się z — jak się okazuje — ogromnym wyzwaniem digitalizacji dalszych krojów pism czekających na swoich cyfrowych wskrzesicieli. Od tej pory tylko 
ignoranci mogą sądzić, że digitalizacja kroju to odtwórcza czynność przerysowania znaków do komputera — nic bardziej mylnego: jak mówi Machalski „to jest jak wykonywanie utworu muzycznego. Chopin skomponował Koncertf-moll, ale pole do interpretacji zapisanych w nim nut jest duże. Inaczej ten sam koncert zagrał Rubinstein, inaczej zaś Szymon Nehring. Oczywiście, w przypadku digitalizacji kroju pisma miejsca na interpretację i ekspresję własną jest dużo mniej, ale na pewno nie można nazwać tej pracy odtwórczą"7. Natomiast mimo tego, że już możemy cieszyć się dziełami złożonymi w komputerowych programach typograficznych, takimi krojami jak Antykwa Toruńska, Antykwa Półtawskiego, Cyklop, a nawet kontrowersyjnym FA Komunikat (opartym na awangardowej propozycji Władysława Strzemińskiego), jeszcze wiele jest do zrobienia. Warto choćby wspomnieć o podobnych (nie tylko w charakterze, ale i problematyce) do Bony krojach Wisła czy Narew, które wciąż zimują w kasztach. Szlak został już przetarty — powodzenia!

\footnotetext{
7 A. Heidrich et al., op. cit., Warszawa 2017, s. 36.
} 